\title{
Copper/Zinc Superoxide Dismutase-Like Immunoreactivity in the Metamorphosing Brain of the Sphinx Moth Manduca sexta
}

\author{
JOACHIM SCHACHTNER, ${ }^{1 *}$ WOLF HUETTEROTH, ${ }^{1}$ ALAN NIGHORN ${ }^{2}$ \\ AND HANS-WILLI HONEGGER ${ }^{3}$ \\ ${ }^{1}$ Fachbereich Biologie, Tierphysiologie, Philipps-Universität, 35032 Marburg, Germany \\ ${ }^{2}$ Arizona Research Laboratories Division of Neurobiology, University of Arizona, \\ Tucson, Arizona 85721 \\ ${ }^{3}$ Department of Biological Sciences, Vanderbilt University, Nashville, Tennessee 37325
}

\begin{abstract}
$\mathrm{Cu} / \mathrm{Zn}$ superoxide dismutase (SOD) is part of the defense mechanism that protects cells from being damaged by reactive oxygen species. During metamorphosis of the nervous system, neurons undergo various fates, which are all coupled to high metabolic activities, such as proliferation, differentiation, pathfinding, and synaptogenesis. We describe the pattern of SOD immunoreactivity of identified neurons and neuron groups in the brain of Manduca sexta from the late larva through metamorphosis into adult. We focused on neurons of the developing antennal lobes, the optic lobes, and the central brain. Our results indicate the transient expression of SOD during phases in which the neurons develop their final adult identities. Our data also suggest that the SOD immunoreactivity may be used as an indicator for the period in which developing neurons form their synapses. We also observed SOD immunoreactivity within nitric oxide-sensitive cells as characterized by immunolabeling against $3^{\prime} 5^{\prime}$-cyclic guanosine monophosphate and soluble guanylyl cyclase, a novel finding in insects. J. Comp. Neurol. 469:141-152, 2004. ๑ 2003 Wiley-Liss, Inc.
\end{abstract}

Indexing terms: development; oxidative stress; cell fate; nitric oxide

In all aerobic organisms, a byproduct of oxygen metabolism is the generation of reactive oxygen species (ROS), which can cause serious damage to any molecule of a cell (Fridovich, 1999). To protect cells against this oxidative threat, cellular defense mechanisms exist. One major player is $\mathrm{Cu} / \mathrm{Zn}$ superoxide dismutase (SOD) which, together with catalase, eliminates superoxides and eventually converts them to $\mathrm{O}_{2}$ and $\mathrm{H}_{2} \mathrm{O}$ (Fridovich, 1986, 1999). According to the oxidative stress hypothesis of aging, ROS are involved in the physiological deterioration of cells that accompanies aging (Ames et al., 1993; Sohal, 1993; Stadtman, 2001; Nagy, 2001; Linton et al., 2001). Nerve cells, with their high metabolic rates (Frayn, 1996), are particularly endangered. Thus, ROS may play a major role in neurodegenerative disorders such as Alzheimer's disease, Parkinson's disease, and amyotropic lateral sclerosis (Markesbery, 1997; Floyd, 1999; Tabner et al., 2001; Beckman et al., 2001; Maier and Chan, 2002; OkadoMatsumoto and Fridovich, 2002).
In developing nervous systems, neuron proliferation, differentiation, pathfinding to final target areas, and synaptogenesis involve high metabolic rates and, thus, more production of ROS. To prevent oxidative damage, maturing neurons that are in the process of axon and dendrite extension and/or synapse formation may be especially safeguarded by transient defense mechanisms, e.g., by the up-regulation of key antioxidant enzymes.

Grant sponsor: Deutsche Forschungsgemeinschaft; Grant number: Scha 678/3-3 (J.S.).

*Correspondence to: Joachim Schachtner, Fachbereich Biologie, Tierphysiologie, Philipps-Universität, 35032 Marburg, Germany.

E-mail: schachtj@staff.uni-marburg.de

Received 4 June 2003; Revised 14 August 2003; Accepted 19 September 2003

DOI 10.1002/cne.10992

Published online the week of December 8, 2003 in Wiley InterScience (www.interscience.wiley.com). 
For Manduca sexta a large body of knowledge exists regarding the various developmental fates of identified neurons in the metamorphosing nervous system (for review see Truman, 1996). Most nerve cells of the adult brain that differentiate during metamorphosis arise from neuroblasts that have been arrested during early larval stages and that start a second phase of proliferation in late larval stages. Among these cells are the neurons of the developing optic and antennal lobes, which have been well examined in terms of the developmental time course of their proliferation and differentiation phases (Monsma and Booker, 1996a, b; Oland and Tolbert, 1996; Hildebrand et al., 1997; Champlin and Truman, 1998, 2000). Other neurons of the CNS, which were functional in the larva, are remodeled during metamorphosis to fit the requirements of the adult animal (Truman, 1996; Weeks, 1999). Another fate of neurons during metamorphosis is programmed cell death, which has been described for many regions of the insect CNS (Ewer et al., 1998; Draizen et al. 1999; Weeks, 1999). We hypothesize that SOD might be up-regulated during phases of neuronal maturation but not in neurons that undergo programmed cell death.

Superoxide also acts as a major limiting factor for the survival of the free radical gas nitric oxide (NO; Ku, 1996). It rapidly reacts with $\mathrm{NO}$ to build peroxynitrite and, thus, drastically limits the signaling abilities of NO. Thus, SOD may enhance NO stability and, additionally, prevents the production of cytotoxic peroxynitrite (Beckman and Koppenol, 1996; Friebe et al., 1998).

To test the hypothesis that developing neurons in the metamorphosing nervous system of $M$. sexta up-regulate SOD as a possible protection mechanism against oxidative damage, we investigated the pattern of antibody staining obtained with a specific antiserum against SOD (Kostron et al., 1999). Here we describe SOD labeling for selected neurons throughout metamorphosis of the M. sexta brain. For many of the neurons examined, we show a colocalization of SOD immunoreactivity with either NO-induced $3^{\prime} 5^{\prime}$-cyclic guanosine monophosphate (cGMP) elevation or an antiserum against the $\alpha_{1}$ subunit of soluble guanylyl cyclase, which NO-dependently produces cGMP (Gibson and Nighorn, 2000).

\section{MATERIALS AND METHODS \\ Animals}

M. sexta (Lepidoptera: Sphingidae) were reared on an artificial diet under a long-day photoperiod (L:D = 17:7) at $26^{\circ} \mathrm{C}$ in walk-in environmental chambers. Under these conditions, the time required from hatching to pupal ecdysis is about 18 days and the time from pupal to adult ecdysis about 20 days. The start of the wandering stage (W0) occurs 3-4 days into the fifth larval instar and is characterized by the appearance of a red pigment along the heart. The following days are referred to as W1 up to W4. At about noon of W2, the animals go into a quiescent prepupal stage. Pupal ecdysis occurs on day W4, and the newly formed pupa is designated as day P0. Subsequent days of pupal development are counted as P1-P20. Adult eclosion occurs around stage P20, and subsequent days of adult life are counted as A0 (freshly eclosed) to A3 (3 days after adult eclosion). Larvae and pupae were staged according to the criteria described by Jindra et al. (1997) and Schwartz and Truman (1983). The criteria involve changes in structures that are either superficial or readily visible through the pupal cuticle under a dissecting microscope.

\section{Western blot analysis}

SDS-PAGE. Brains of various insect species [M. sexta (various developmental stages), Drosophila melanogaster (white puparia), Gryllus bimaculatus (adult), Leucophaea maderae (adult), Schistocerca gregaria (adult)] and pieces of cortices of rat (Rattus norvegicus) and mouse (Mus musculus) were homogenized in phosphate-buffered saline containing protease and phosphatase inhibitors [0.5 $\mathrm{mM} \mathrm{Na} \mathrm{NO}_{4}, 0.5 \mathrm{mM}$ phenylmethylsulfonyl fluoride (PMSF); both Sigma-Aldrich Chemie GmbH, Munich, Germany]. After determination of protein concentration of the samples after Bradford (1976), homogenates were diluted to an equal total protein concentration of $7.5 \mu \mathrm{g}$ or $6 \mu \mathrm{g} / 9$ $\mu l$. To $9 \mu$ l of homogenate $9 \mu$ l reducing sample buffer, $\mathrm{pH}$ 6.8 , was added. After 3 minutes of boiling, samples were loaded onto a discontinuous sodium dodecyl sulfate (SDS)polyacrylamide gel (3\% stacking gel, $12.5 \%$ running gel) in a Bio-Rad Mini-Protean 3 chamber and blotted to a nitrocellulose membrane (Hybond C; Amersham Biosciences Europe, Freiburg, Germany), with a semidry transfer apparatus (Bio-Rad, Hercules, CA). To control the efficiency of protein transfer, nitrocellulose membranes were stained after transfer with Ponceau red.

Immunoblot. Blots were blocked in phosphatebuffered saline (PBS; $0.1 \mathrm{M}, \mathrm{pH}$ 7.4) containing $0.05 \%$ Tween $20,1 \%$ casein, and $20 \%$ fetal bovine serum for 1 hour and then incubated with the SOD antiserum (S2; $1: 1,000)$ at $4^{\circ} \mathrm{C}$ overnight in PBS $(0.1 \mathrm{M})$ containing $0.05 \%$ Tween 20 (PBST). For preabsorption, the SOD antibody (Kostron et al., 1999; 1:1,000) was incubated for 30 minutes at room temperature with $100 \mu \mathrm{mol}$ of synthetic peptide. Blots were washed three times for 10 minutes each in PBST, $1 \%$ Triton X-100, and 1\% SDS. A horseradish peroxidase (HRP)-coupled goat anti-rabbit secondary antiserum (1:5,000; Jackson Immunoresearch, West Grove, PA) was applied for 1 hour at room temperature in PBST. After being washed, blots were developed by chemiluminescence using Supersignal from Pierce (Rockford, IL) according to the instructions of the manufacturer. The signal was visualized with X-ray films (Fuji), digitized, and further processed in Adobe Photoshop 6.0 and Microsoft's PowerPoint.

\section{Immunocytochemistry}

We used as primary antibodies a polyclonal anti-SOD antiserum from rabbit (S2; 1:10,000; Kostron et al., 1999), a polyclonal anti-cGMP antiserum from sheep (1:4,000; kindly provided by Jan DeVente, Limburg University, Maastricht, The Netherlands), a polyclonal anti-sGC $\alpha 1$ against $M$. sexta soluble guanylyl cyclase $\alpha 1$ subunit from goat at 1:5,000, and a monoclonal anti-synaptotagmin antibody from mouse (1:2,500; kindly provided by Kaushiki Menon, Caltech). Specificity controls for the anti-SOD, anti-cGMP, anti-sGC $\alpha 1$, and anti-synaptotagmin antibodies were described by Kostron et al. (1999), De Vente et al. (1987), Ewer et al. (1994), Gibson and Nighorn (2000), and Dubuque et al. (2001). The following secondary antibodies (from Jackson Immunoresearch) were used at a dilution of 1:300: HRP-coupled goat anti-rabbit, Cy2-coupled donkey anti-sheep, Cy3-coupled donkey/goat anti-rabbit/goat, and Cy5-coupled donkey/goat anti-mouse antibodies. 
After dissection in cold saline (Weevers, 1966) or PBS, brains of various developmental stages of $M$. sexta were fixed in $4 \%$ PBS-buffered formaldehyde, $\mathrm{pH} \mathrm{7.4,} \mathrm{for} 2$ hours at room temperature or overnight at $4^{\circ} \mathrm{C}$. After fixation, brains were embedded in gelatin/albumin, postfixed overnight in $8 \%$ buffered formaldehyde, and cut at 40 $\mu \mathrm{m}$ with a Vibratome (Leica VT 1000S) in the frontal plane. Vibratome sections were rinsed in $0.1 \mathrm{M}$ Tris $\mathrm{HCl}$ (Sigma-Aldrich Chemie GmbH)/0.3 M NaCl (SST; pH 7.4) with $0.1 \%$ Triton X-100 (SST-TX 0.1) for 1 hour at room temperature, then preincubated for another hour with $5 \%$ normal goat or donkey serum (Jackson Immunoresearch) in SST-TX 0.5. Primary antibodies were then diluted in SST-TX 0.5 with $1 \%$ normal goat or donkey serum. After incubation with the primary and secondary antisera, sections were rinsed three times over 30 minutes in SST-TX 0.1 at room temperature.

For multiple labeling, the cGMP antibody and the corresponding secondary antibody were used first, and afterward anti-SOD and anti-synaptotagmin antisera were applied simultaneously and also after washing of the corresponding secondary antisera. HRP was visualized on free-floating sections with 3.3'-diaminobenzidine (DAB; Sigma-Aldrich Chemie $\mathrm{GmbH}$ ) by using the glucose oxidase (Sigma-Aldrich Chemie $\mathrm{GmbH}$ ) technique according to Watson and Burrows (1981). Sections were mounted on chromalaun/gelatin-coated coverslips and then dehydrated in ethanol, cleared in xylene, and mounted in Entellan (Merck, Darmstadt, Germany). Alternatively, brains after the fixation process (see above) were dehydrated through a graded ethanol series and xylene and then embedded in Paraplast Plus (Monoject Scientific, St. Louis, MO). Sections were cut at $8 \mu \mathrm{m}$ on a rotatory microtome, dried on gelatin-coated slides, deparaffinized, and rehydrated. The anti-SOD antiserum (S2) was used at a dilution of 1:1,000, the secondary goat anti-rabbit HRPcoupled antiserum at 1:300. Incubation times and solutions were used as described above. Visualization of HRP was carried out with $\mathrm{DAB}$ as a chromophore as described in detail by Homberg et al. (1987). Afterward, sections were rehydrated in ethanol and mounted in Entellan. Sections were photographed with a Polaroid DMCe digital camera mounted on a Zeiss Axioscope, imported into Adobe Photoshop 6.0, and annotated in Microsoft PowerPoint. Doubly or triply fluorescence-labeled sections were analyzed with a confocal laser scanning microscope (Leica TCS-SP2).

\section{Detection of programmed neuronal death}

To detect cells undergoing programmed cell death, a detection kit from Roche Diagnostics (Mannheim, Germany) was used. The kit is based on the terminal deoxynucleotidyl tranferase (TdT)-mediated dUTP nick-end labeling (TUNEL) method and was used according to the manufacturer's manual. Vibratome sections of Manduca brains were produced as described above. Sections were rinsed three times over 30 minutes in SST-TX 0.1 at room temperature and then incubated in wellplates (Falcon) for 15 minutes in $500 \mu$ l reaction buffer ( $\mathrm{pH}$ 6.6) containing $200 \mathrm{mM}$ Na-cacodylate, $25 \mathrm{mM}$ Tris $\mathrm{HCl}, 1 \mathrm{mM}$ cobaltic chloride, $0.25 \mathrm{mg} / \mathrm{ml}$ bovine serum albumin, and $0.1 \%$ Triton $\mathrm{X}$. The reaction buffer was then exchanged with $225 \mu \mathrm{l}$ of the reaction solution $(120 \mu \mathrm{l}$ distilled water, $30 \mu \mathrm{l}$ reaction buffer; $\times 5$ ), $67.5 \mu$ l of the kit's nucleotide solution (TMR red dUTP), and $7.5 \mu$ l of the kit's enzyme solution
(TdT). Controls were processed without the enzyme solution. Sections were incubated in the dark in the reaction buffer for 4 hours at $37^{\circ} \mathrm{C}$ on a shaker. Then, sections were rinsed four times for 15 minutes each in PBS TX 0.1 and then for a further 10 minutes in PBS alone. Sections were then arranged on coverslips, dehydrated, cleared, and mounted in Entellan as described above. TMR red was visualized by using a confocal laser scanning microscope (Leica TCS-SP2). TUNEL labeling was combined with antibody staining by performing the protocol described above after finishing the TUNEL reaction. Secondary antibodies coupled to Cy2 or Cy5 were used because they can be distinguished from the red fluorescence of TMR red.

\section{RESULTS Western blot analysis}

The antibody used in this study was produced against residues 40-55 of SOD of Drosophila virilis (Kostron et al., 1999). Residues 40-55 represent a highly conserved sequence of SODs of all animal species so far examined (Kostron et al., 1999). In this region, SOD binds a copper molecule that is involved in electron transport (Fridovich, 1986).

To demonstrate the specificity of this antiserum and to show its ability to detect SOD from different species, we performed Western blots from SDS gels run under reducing conditions and loaded with brain tissue homogenates of various insects $[M$. sexta, D. melanogaster (white puparia), Leucophaea maderae, Schistocerca gregaria, Gryllus bimaculatus] and two mammalian species (mouse, rat). In all lanes, one prominent protein band at about 15 $\mathrm{kDa}$ was labeled (Fig. 1A,B). Preadsorption of the SOD antiserum with the synthetic 15-residue peptide abolished all labeling in the Western blots (Fig. 1A) and in the sectioned material (not shown), demonstrating that the antiserum used specifically recognizes the monomeric form of SOD throughout all species tested. The SOD antiserum detects the $15-\mathrm{kDa}$ band in all developmental stages, from fifth-instar larva during metamorphosis to the adult (Fig. 1C)

\section{Developmental pattern of SOD-like immunoreactivity}

During metamorphosis the SOD antiserum transiently labeled many cells virtually in every part of the brain of $M$. sexta, including neurons in the optic lobes, antennal lobes, central brain, and subesophageal ganglion (Figs. 2-4). During all phases of development, the antiserum labeled neurons and, rarely, glial material (Fig. 5). The antiserum labeled only the neuronal cell bodies and, in a few cases, small parts of the neurite leaving the cell body (Figs. 2-5).

With only the somata labeled, it was difficult to identify neurons unequivocally by comparison with published data and also to recognize the same neurons in different stages, in that neighboring cell bodies might gain SOD immunoreactivity (-ir). In spite of these ambiguities, some cells and especially cell groups could reliably be identified. For example, in the antennal and optic lobes, the time course of the SOD-ir could be followed throughout late larval and pupal development (Fig. 6). The results show that, in the brain areas investigated, most neurons expressed SOD-ir through distinct developmental stages, whereas some neurons showed expression at all times examined. We focused on those cell types that showed changes in expression. 


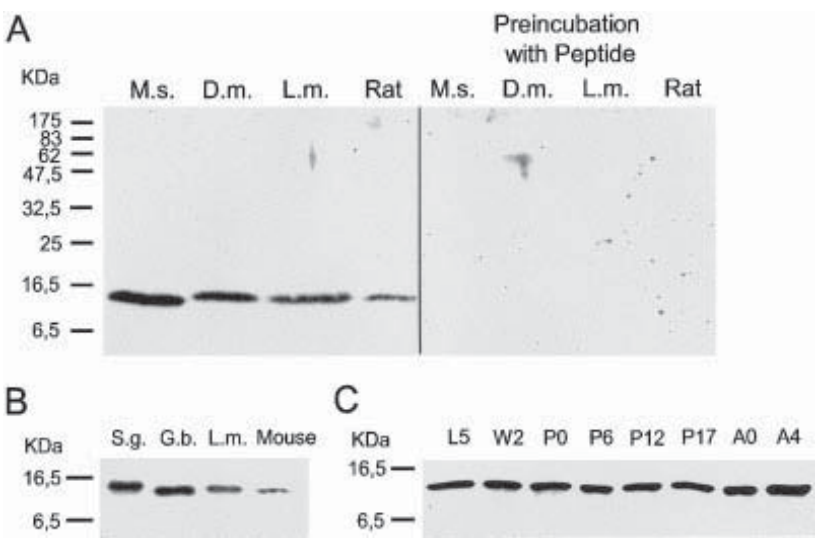

Fig. 1. Immunodetection of SOD in nervous system homogenates of various animals with the anti-SOD antiserum. A: The SOD antiserum labels a unique protein band at about $15 \mathrm{kDa}$ in blots of polyacrylamide gels loaded with brain homogenates of Manduca sexta adult (M.s.), Drosophila melanogaster white puparia (D.m.), Leucophaea maderae adult (L.m.), and rat cortex (rat) and run under reducing conditions. After preincubation with synthetic peptide, no signal was detectable in either of the homogenates. B: Brain homogenates of further species tested show a labeled protein band at about $15 \mathrm{kDa}$. Schistocerca gregaria adult (S.g.), Gryllus bimaculatus adult (G.b.), cortex of mouse brain (mouse). C: SOD immunodetection during $M$. sexta brain metamorphosis. The approximately $15-\mathrm{kDa}$ band was detected in all developmental stages. L5, fifth-instar larva; W2, 2-day-old wandering larva (fifth instar); P0-P17, pupal stages of $M$. sexta; A0, freshly eclosed adult; A4, 4-day-old adult. In A and B, single brains were homogenized and a total of $7.5 \mu \mathrm{g}$ protein/lane was loaded; in $\mathrm{C}$, four brains for each stage were homogenized and a total of $6 \mu \mathrm{g}$ protein/lane was loaded.

\section{Neurons in the antennal lobe}

We followed SOD-ir in the lateral (LC) and the medial cell group (MC; defined by Homberg et al., 1988) in the antennal lobe. The neurons with somata in these two groups together with the olfactory receptor neurons are the principal neurons organizing the glomeruli. These neurons are present from early pupal stage P3, and the cell groups can be unequivocally identified during metamorphosis (Hildebrand et al., 1997). In any given stage from P7 to adulthood, the SOD antiserum labels cell bodies in $\mathrm{LC}(\mathrm{n}=35$; Figs. 2, 6). However, in the different developmental stages, the number of cells stained, and the staining intensity within those cells, varied appreciably (Fig. 2). We distinguished, according to the pattern of SOD-ir in LC, five metamorphic phases. In the first phase from P0 up to P6, no SOD-ir was detected in the LC ( $\mathrm{n}=$ 16). In a second phase from P7 to P11/12, most cells of LC were labeled with the SOD antiserum $(\mathrm{n}=14)$. The labeled cells in this second phase can be distinguished into two groups: a smaller group consisting of very robustly stained cells and a much larger group of very faintly stained cells (Fig. 2A). Double labeling with the cGMP antiserum showed that all cGMP-immunoreactive cells were also intensely labeled with the anti-SOD antiserum (Fig. 2A-C). As previously described (Schachtner et al., 1999), the cGMP-immunoreactive cells in the LC belong to the group of local neurons, and they account during this time of development for about one-tenth of the approximately 1,000 cells in the LC. In a third metamorphic phase spanning stages P12/13 up to adult eclosion, faint
SOD-ir appeared in small populations of cells in LC ( $\mathrm{n}=$ 15). In a fourth phase starting at adult eclosion (A0) and ending on adult day one to two (A1/2), scattered cells with robust and weakly labeled SOD-ir were found among nonlabeled cells ( $\mathrm{n}=8$; Fig. 2C,D). A subpopulation of the weak SOD-immunoreactive neurons showed additional staining with an antiserum against the $\alpha 1$ subunit of NO-sensitive guanylyl cyclase (sGC $\alpha 1$; Fig. 2D; Gibson and Nighorn, 2000). Somata with strong SOD-ir never colocalized sGC $\alpha 1$-ir (double arrowheads in Fig. 2D). Most of the approximately 60 sGC $\alpha 1$-positive cells $(n=6$ antennal lobes) in A0 and A1 showed weak SOD-ir, and there are only a few sGC $\alpha 1$-immunoreactive cells that do not stain with the SOD antiserum (arrowhead in Fig. 2D). Phase five, lasting from A3 until the death of the animal, showed no SOD-ir in the LC $(\mathrm{n}=5)$.

In neurons of the MC, SOD-ir can be detected in a window ranging from stage $\mathrm{P} 13 / 14$ up to $\mathrm{P} 17$ ( $\mathrm{n}=12$; Figs. 2,6). SOD-ir in MC resembles that seen in LC in the same developmental window (phase three): very faint SOD-ir occurring in varying numbers of cells (Fig. 2B).

\section{Neurons in the optic lobes}

SOD-ir was detectable in cell cortices of the developing optic neuropils from the onset of the wandering stage (W0; $\mathrm{n}=5$ ). At, or shortly before, pupal ecdysis (P0), SOD-ir disappeared and was again detectable at P1 $(n=3)$. SOD-ir was never observed in the optic anlagen themselves (Fig. 3A). The optic anlagen house the neuroblasts of the optic lobes (for details, see Discussion). From P3/4 on, cell bodies of the appearing three optic neuropils are labeled with the SOD antiserum (layers 1-3 in Fig. 3C). Most cells distal to the lobula and the medulla neuropil showed strong SOD-ir from P3/4 to P11 $(n=23)$. After P11 and up to adult eclosion, a few weakly labeled somata could occasionally be seen in these areas $(n=19)$. Somata of the medulla cortex belonging to the medulla stripe (MS; Schachtner et al., 1998) showed intense SOD labeling from P5 to P15 $(\mathrm{n}=30)$. In the outer optic neuropil, the lamina, presumptive second-order visual neurons (lamina monopolar cells) robustly labeled with the SOD antiserum from P3/4 up to P8 $(n=18)$. From P9-P11, a few weakly labeled somata could be found in this area $(n=7)$.

Another group of neurons that showed SOD-ir from P1/2 into adulthood was located at the base of the lobula and medulla (bLM neurons; Fig. 3B,D-F,J; $\mathrm{n}=57$ ). These neurons with cell bodies of varying sizes probably belong to neurons innervating the lobula and medulla (Homberg and Hildebrand, 1989; Homberg et al., 1990). Among these neurons were a ventrally and a dorsally located cell cluster consisting of somata ( $\mathrm{VCl}$ and $\mathrm{DCl}$, respectively, both consisting of a few hundred cells) that transiently elevated cGMP levels during optic lobe development (VCl from $\mathrm{P} 4$ to P15; DCl from P7 to P15; Schachtner et al., 1998). Doublelabeling experiments in a P8 optic lobe showed that most if not all of the DCL neurons colocalize SOD-ir and cGMP-ir (Fig. 3F). In the $\mathrm{VCl}$, a group of the cGMP-positive cells did not stain with the SOD antiserum (Fig. 3E). Additionally, cell bodies of similar size in close proximity to $\mathrm{VCl}$ and DCl showed equally strong SOD-ir but no cGMP-ir (Fig. 3E,F).

From P2/3 up to P15, two to four large cell bodies located dorsoposteriorly in the vicinity between the optic lobe and central brain showed robust SOD-ir (Fig. 3C; $\mathrm{n}=35$ ). From P15 to adult eclosion, these putative lobula giant neurons (Homberg and Hildebrand, 1994) showed only 

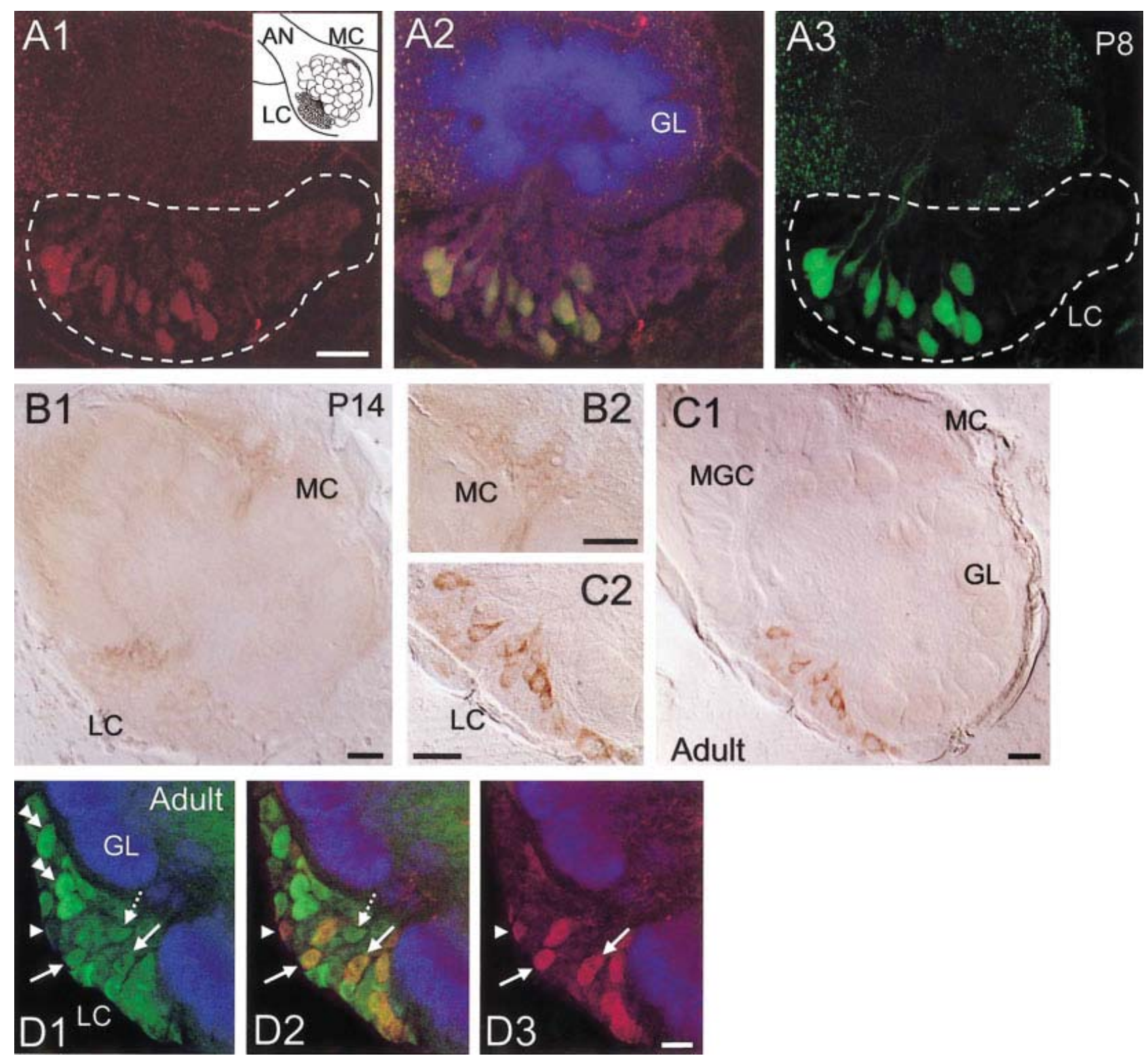

Fig. 2. SOD-ir during antennal lobe (AL) development and colocalization with cGMP-ir and sGC $\alpha 1$-ir. A1-A3: Triple labeling in a P8 AL: SOD-ir (red), synaptotagmin-ir (blue), cGMP-ir (green). SOD-ir in the lateral cell group (LC; encircled) is colocalized with cGMP-ir. Other cells of LC are not labeled or are weakly labeled with the SOD antiserum. A2 is a merged image of A1 and A3. Synaptotagmin-ir in A2 labels the developing glomeruli. Inset in A1 shows the orientation of the AL. B: SOD-ir in P14 AL is weak in LC and in the medial cell group (MC). B2 shows a magnification of the $\mathrm{MC}$ in B1. C: SOD-ir in adult ALs is restricted to LC. C2 shows a magnification of LC in C1.

Note the differences in the intensities of the labeled cell bodies. D1-D3: Triple labeling in an adult AL: SOD-ir (green), synaptotagmin-ir (blue), sGC $\alpha 1$-ir (red). SOD-ir and sGC $\alpha 1$-ir colocalize in LC cell bodies weakly labeled with the SOD antiserum (solid arrows). The strongest SOD-ir labeled cells never show sGC $\alpha 1$-ir (double arrowheads). The arrowhead marks a cell body labeled with sGC $\alpha 1$-ir but not SOD-ir. The dotted arrow points to a weakly SODpositive cell that is not labeled with sGC $\alpha 1$. Vibratome $40 \mu \mathrm{m}$ sections, frontal views. Scale bars $=40 \mu \mathrm{m}$ in A,D, $50 \mu \mathrm{m}$ in B,C.

weak SOD-ir (Fig. $3 \mathrm{H}, \mathrm{n}=10$ ). This changed again to very robust SOD labeling at adult eclosion (Figs. 3I, 6; $\mathrm{n}=3$ ). In the adult, SOD-ir colocalized in these cells and in most of the bLM neurons with sGC $\alpha 1$ labeling (Fig. 3I,J). SOD-ir in the putative lobula giant neurons and in the bLM neurons faded from adult day 1 (A1) and was then absent in A3 (Fig. 6) and older animals $(\mathrm{n}=7$ ).

\section{Neurons in the central brain}

In the central brain, many neurons label with the SOD antiserum (Figs. 4,6). We choose four different groups to follow through pupal development, according to their location. 1) Large cell bodies in the pars intercerebralis (PI) showed robust SOD-ir already in the late fifth larval in- 


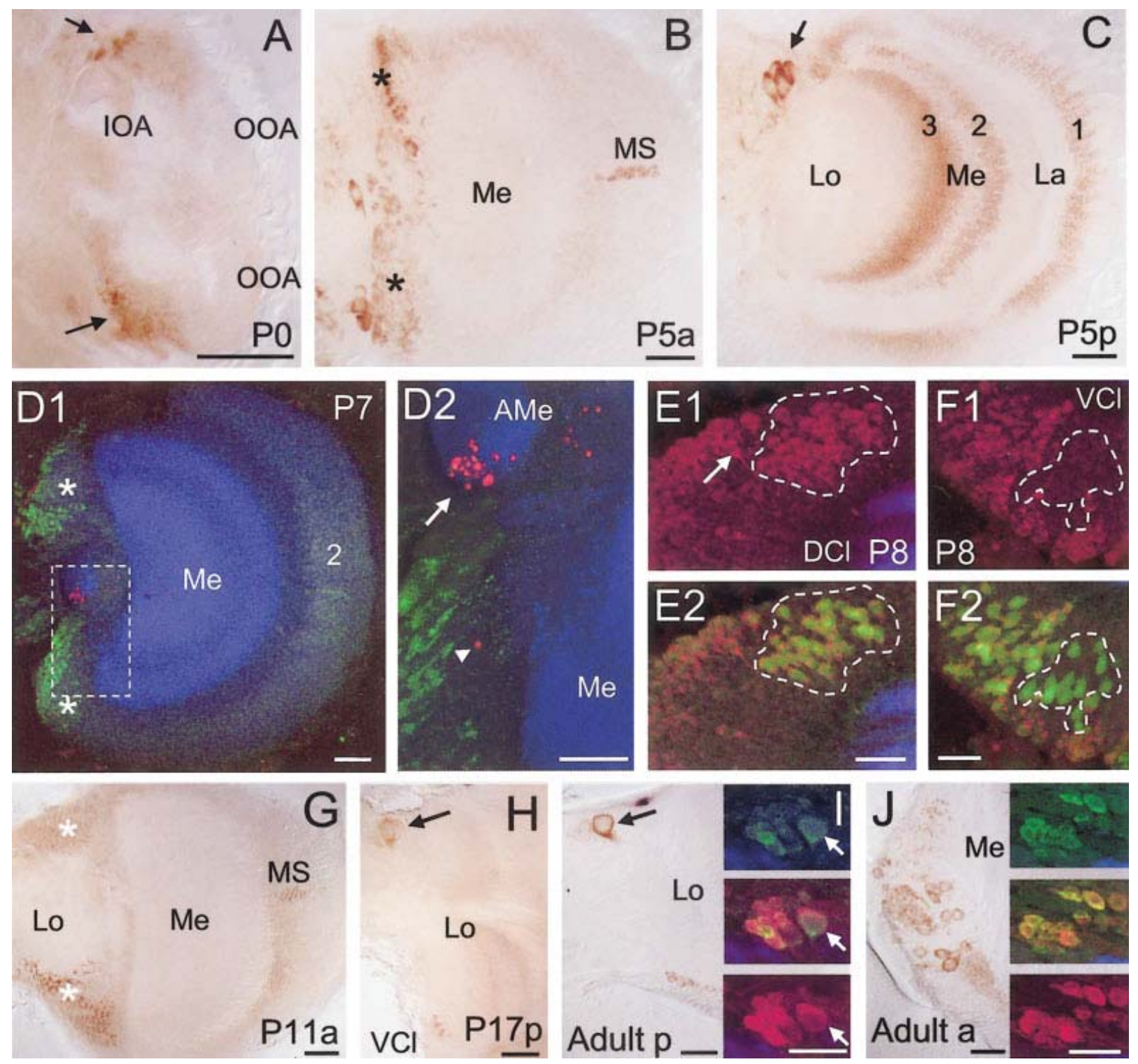

Fig. 3. SOD-ir during optic lobe development. A: At P0, cells in the optic lobe cortex stain with the SOD antiserum (arrows). Neuroblasts in the inner (IOA) and outer optic anlagen (OOA) are not labeled. B,C: Anterior (P5a) and posterior (P5p) sections of a P5 OL. B: Cell bodies of variable size at the basis of lobula and medulla (bLM neurons) showed robust SOD-ir (asterisks). C: Most of the neurons surrounding the three optic neuropils (layers 1-3) show strong SOD-ir; neurons in layer 1 are mainly putative lamina monopolar cells. The arrow marks putative lobula giant (LoG) neurons. D: Triple labeling with the SOD antiserum (green), synaptotagmin antibody (blue), and TUNEL labeling (red) in a P7 optic lobe. D2 is a magnification of the boxed area in D1 showing dying neuroblasts of the IOA (arrow) and one TUNELlabeled nucleus in the area of the medulla (arrowhead) of an SODnegative cell. E,F: Triple immunolabeling in the dorsal (DCl; E) and the ventral (VCl; F) cell cluster of a P8 optic lobe; SOD-ir (red), Syt-ir

star (the earliest time we looked at SOD-ir) up to adulthood (Fig. $4 \mathrm{E} ; \mathrm{n}=66$ ). It is uncertain whether the same cells were labeled in the different developmental stages. 2) In the Kenyon cells of the mushroom bodies (MB) in $M$. (blue), cGMP-ir (green). E1,2: In DCl all cGMP-ir cells show SOD-ir (stippled area). There are additional SOD-immunoreactive neurons that do not label with the cGMP antiserum (left of the encircled area). F1,2: In VCl, many SOD-positive neurons colabel with cGMP-ir. The encircled area shows $\mathrm{VCl}$ neurons that label only with the cGMP antiserum. G: Anterior section of a P11 OL showing SOD-ir in the ventral and dorsal cell cortices of lobula and medulla. H: P17. Faint SOD-ir in LoG neurons (arrow) and some cells in the area of $\mathrm{VCl}$. I,J: Robust SOD-ir in adult OL can be found in putative LoG neurons (arrows) and in many bLM neurons. Upper insets in I and J show SOD-ir (green), lower insets sGC $\alpha 1$-ir, and middle insets an overlay of both. a, Anterior; b, posterior; La, lamina. Vibratome $40 \mu \mathrm{m}$ sections, frontal views. Scale bars $=80 \mu \mathrm{m}$ in A-C,D1,G-J, $40 \mu \mathrm{m}$ in $\mathrm{D} 2, \mathrm{E}, \mathrm{F}$.

sexta, transient SOD-ir can be divided into five phases. In a first phase from P0 to P3/4, a few Kenyon cells weakly labeled with the SOD antiserum $(\mathrm{n}=6)$. A second phase lasting for about 12-13 days (from P3/4 to P15/16) is 

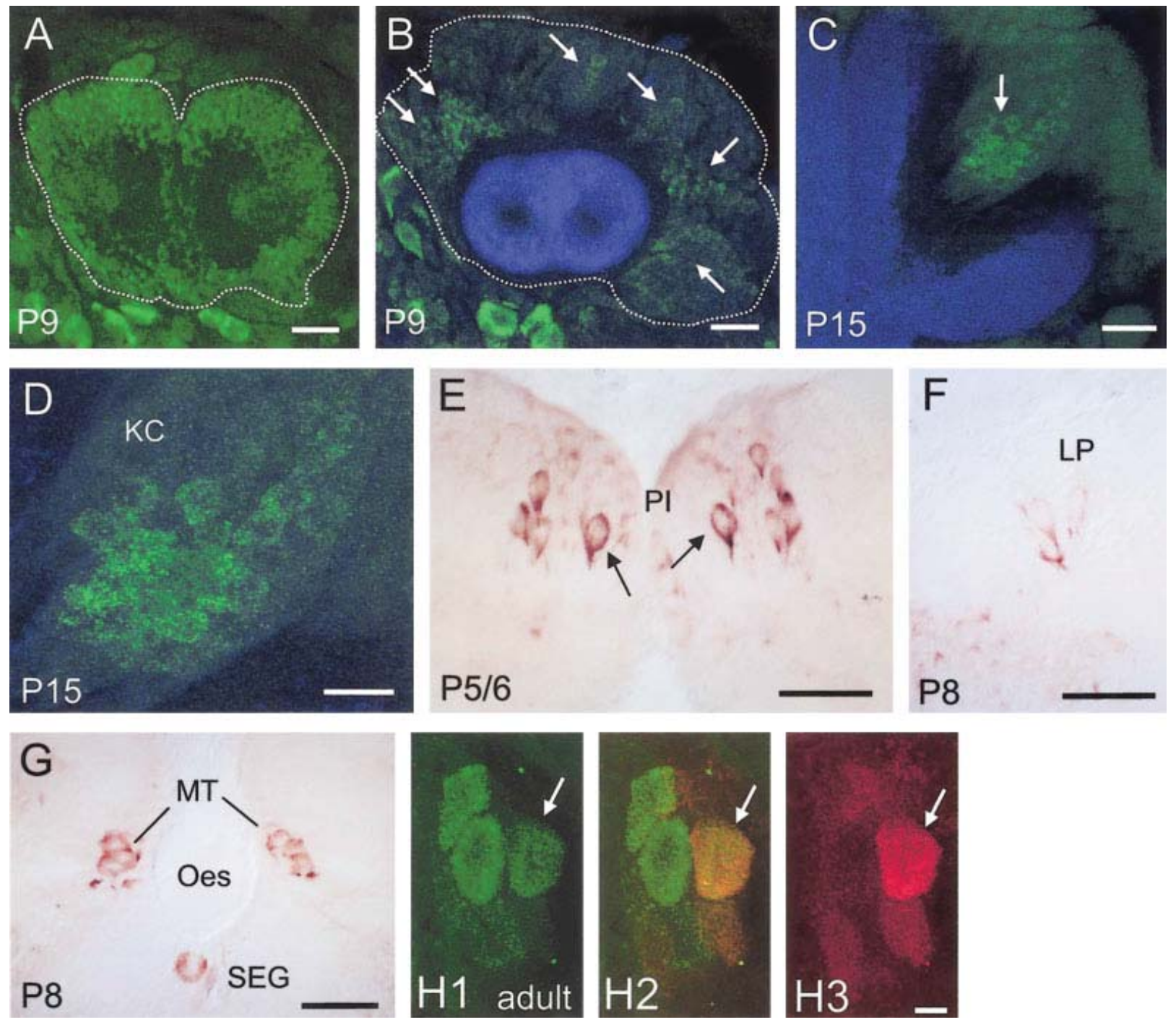

Fig. 4. SOD-ir during central brain development. A-D: SOD-ir (green) in the Kenyon cells (KC) of the mushroom bodies. Blue, synatotagmin-ir. A and B are sections of the same mushroom body of a P9 pupal brain, A being posterior to B. Typically for a more posterior view (A), most if not all of the Kenyon cells of the MB (encircled) are labeled with the antiserum. Typically for a more anterior position (B), single clusters of KC show SOD-ir (MB area encircled). C: A typical cluster of SOD-immunoreactive KC (arrow) in a P15 pupa. D: shows a magnification of the KC cluster in C. E: Strong transient SOD-ir in

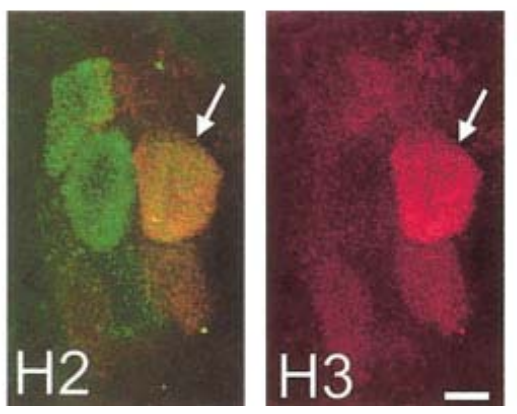

large cell bodies (arrows) of the pars intercerebralis (PI) in a P5/6 pupa. F: SOD-ir in large neurons in the lateral dorsal protocerebrum (LP) at stage P8. G: Labeling of large neurons in the medial tritocerebrum (MT neurons) and in large cells at the anterior dorsal end of the subesophageal ganglion (SEG). H: Double labeling of cells in the medial tritocerebrum of an adult animal with SOD-ir in green (H1) and sGC $\alpha 1$-ir in red (H3). H2 shows an overlay of both. Vibratome sections, $40 \mu \mathrm{m}$ frontal views. Scale bars $=40 \mu \mathrm{m}$ in A-C, $100 \mu \mathrm{m}$ in $\mathrm{E}-\mathrm{G}, 20 \mu \mathrm{m}$ in $\mathrm{D}, \mathrm{H}$.

characterized by robust SOD-ir in many Kenyon cells (Fig. $4 \mathrm{~A}-\mathrm{D})$. Most if not all Kenyon cells in the posterior part of the MB showed staining in many of these preparations (23 of 26; Fig. 4A). In the middle and anterior portions of the MB, SOD-ir occurred only in clustered groups of Kenyon cells (Fig. 4B). In a third phase spanning the rest of pupal development, no or very weak overall SOD-ir could be detected $(n=7)$. The fourth phase spans the time right after adult eclosion (A0) when most if not all Kenyon cells showed SOD-ir (not shown; $\mathrm{n}=3$ ). In a fifth phase starting from 1-day-old adults (A1) and lasting probably for the rest of the animals' lives, no SOD-ir occurs in Kenyon cells

$(\mathrm{n}=10) .3)$ In the lateral protocerebrum, a prominent group of two to four large cell bodies stains positively with the SOD antiserum from L5 up to adulthood (Fig. 4F; $\mathrm{n}=$ 64). As for the PI neurons, we are uncertain whether the same cells were labeled in the different developmental stages. 4) In the median tritocerebrum, on each side of the gut opening, a group of two to six large SODimmunoreactive cell bodies could be followed from P0 up to adulthood (Fig. 4G; $\mathrm{n}=58$ ). In the adult, at least one of these cells could be double labeled with the anti-sGC $\alpha 1$ antiserum (Fig. 4H). It connects both tritocerebral areas via a neurite crossing the midline above the gut opening 

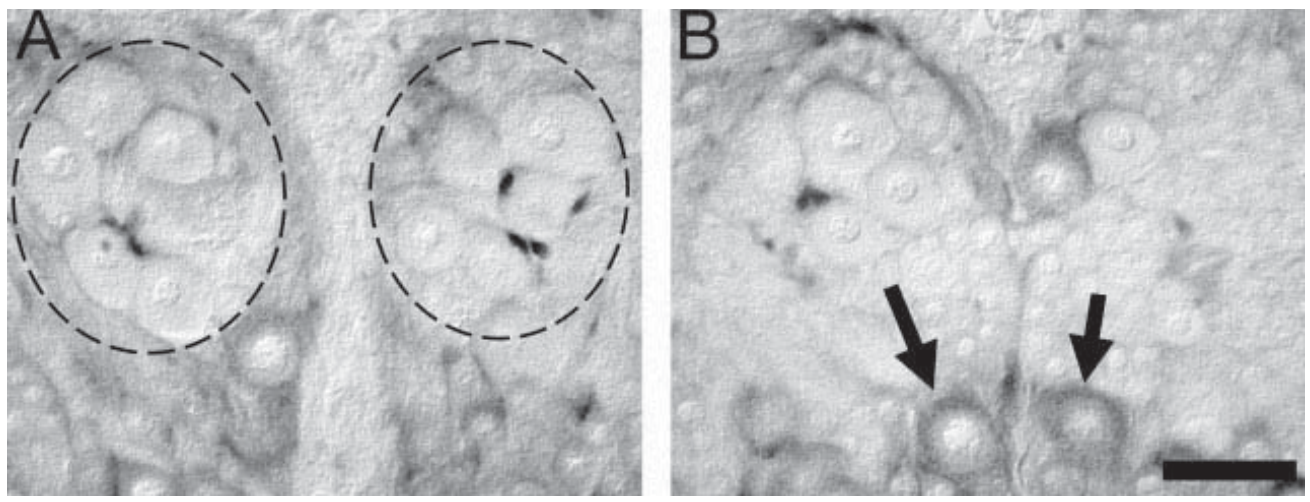

Fig. 5. SOD staining in the dorsal protocerebrum of a P10 pupa. A: SOD-ir in prospective glial material between neuronal cells (encircled regions). B: Typical staining of neuronal cell bodies (arrows). Paraffin sections $(10 \mu \mathrm{m})$, frontal views. Scale bar $=50 \mu \mathrm{m}$.

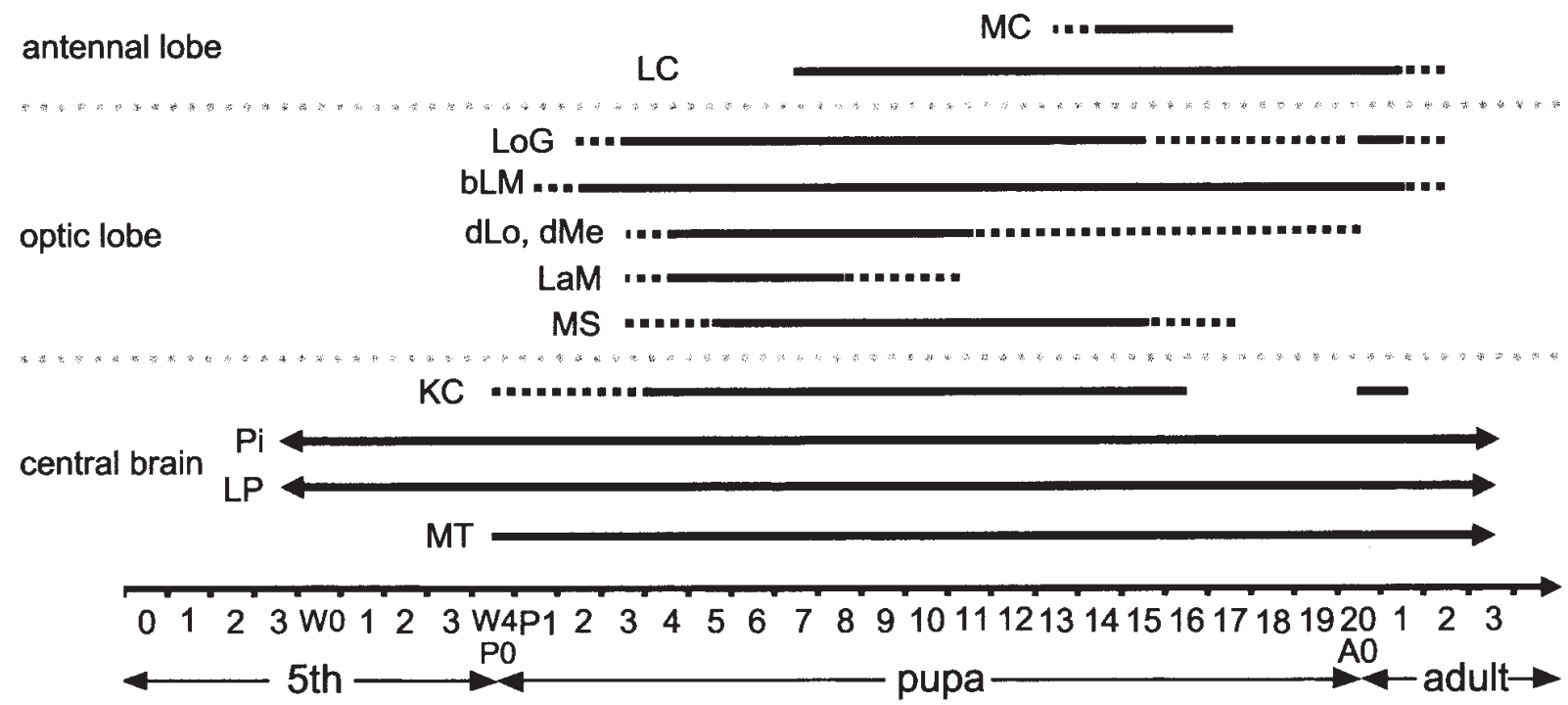

Fig. 6. Diagram showing transient SOD-ir in identified neurons or neuron populations during $M$. sexta development. For further explanation, see text. bLM, Neurons at the basis of lamina and medulla; $\mathrm{dLo}$ and $\mathrm{dMe}$, neurons distal to the lobula and medulla, respectively; KC, Kenyon cells; LaM, lamina monopolar cells; LC, lateral cell group

(Schachtner et al., 1998). Inducible cGMP-ir in this MT cell started with the prepupal stage (W2) and lasted up to pupal stage P14.

\section{TUNEL labeling}

TUNEL labeling (Gavrielli et al., 1992) is an indicator for programmed cell death. Cells that undergo programmed cell death may not show any SOD-ir. We found many cells with TUNEL-labeled nuclei throughout development in the optic lobes but only a few cells in the central brain. We never detected TUNEL-labeled nuclei in the antennal lobe neurons. In the optic lobes, TUNEL-labeled nuclei could be detected from W0 all over the optic lobe cortices and from P7 in neuroblasts of the inner and outer optic anlagen. Figure 3D shows an example of putative dying neuroblasts of the inner optic anlagen. Colocaliza- of the antennal lobe; LoG, lobula giant neuron; LP, lateral protocerebrum cells; MC, medial cell group of the antennal lobe; MS, medulla stripe; MT, median tritocerebrum cells; $\mathrm{Pi}$, pars intercerebralis cells; W0, start of wandering behavior; W4, 4 days after start of wandering. Scale is days of larval and pupal development.

tion of SOD-ir in cells with TUNEL-labeled nuclei was never observed.

\section{DISCUSSION \\ SOD}

$\mathrm{Cu} / \mathrm{Zn}$ SOD, the cytoplasmic form of SOD, together with catalase converts superoxide to molecular oxygen and water (Fridovich, 1986; Oury et al., 1999). Drosophila mutants lacking SOD and/or catalase showed greatly reduced life spans (Mackay and Bewley, 1989; Phillips et al., 1989; Kwiatowski et al., 1991; Orr et al., 1992; Griswold et al., 1993). Drosophila that overexpressed either $\mathrm{Cu} / \mathrm{Zn}$ or $\mathrm{Mn}$ SOD (another form of SOD in mitochondria) showed longer life spans than were observed in wild-type animals 
(Sun and Tower, 1999; Sun et al., 2002; Mockett et al., 2002). Both types of mutants strongly support the idea that both SODs are crucial for protection against ROS.

In this work, we used a previously produced specific antiserum against $\mathrm{Cu} / \mathrm{Zn}$ SOD from $D$. virilis (Kostron et al., 1999). The antiserum was made against a sequence of 15 amino acids located in the highly conserved copperbinding domain of the enzyme. As expected, we could label SOD in various species, including mammals and insects (Fig. 1). In adult Wistar rats as well as in adult Periplaneta americana, SOD seems to be restricted mainly to glial cells (Kostron et al., 1999; Lindenau et al., 2000). We observed $\mathrm{Cu} / \mathrm{Zn}$ SOD-ir mainly in neurons during metamorphosis and in the early adult and found some SOD-ir in glial-like material (Fig. 5). SOD labeling in rats and $P$. americana was never examined during development, so transient neuronal expression of SOD during development cannot be excluded. We observed SOD-ir in $M$. sexta only in very few brain neurons of adult animals older than 3 days. Similar to the case in Manduca, in Drosophila little or no SOD seems to be expressed in the adult, as shown by reporter gene expression, suggesting that other antioxidants might compensate for this deficit (Klichko et al., 1999).

\section{SOD expression during metamorphosis}

During all stages of pupal development, and in the early adult, many cells in the brain were labeled with the SOD antiserum. Three days after adult eclosion, the SOD signal ceased totally in most of the neurons but was detectable in some of the cell types in the central brain (Fig. 6). We followed SOD-ir in only a small number of neurons or neuron groups that we could reliably identify and investigated the immunoreactivity only during defined developmental stages. The majority of other neurons that did or did not show SOD-ir during these stages was not examined further. The unlabeled cells may express SOD at some point of their development that we did not investigate. Alternatively, other protection mechanisms against ROS might play a role in those cells.

\section{Antennal lobe development}

The antennal lobe is the first integration center for odor information in the insect brain. Building blocks of the antennal lobe are the glomeruli, which in $M$. sexta are formed during metamorphosis (Oland and Tolbert, 1996). Each glomerulus consists of thousands of synapses between olfactory receptor neurons, local and projection neurons. A wave of synaptogenesis starts at stage P7/8 at the sexual-specific glomeruli near the entrance of the antennal nerve and ends within the most basally located glomeruli of the antennal lobe. This synaptogenic wave over the antennal lobe ends at P12/13, with glomeruli showing a dense synaptic pattern (Dubuque et al., 2001). From $\mathrm{P} 13$, the glomeruli increase in size, but the number of synapses seems not to increase until adult eclosion (Tolbert et al., 1983; Tolbert, 1989).

Most neurons of the antennal lobe belong to the group of adult-specific neurons, which are all born by P3 (Hildebrand et al., 1997). At stage P7/8, when the antennal lobe neurons start to form synapses and the glomeruli mature, neurons in the lateral cell group became SOD immunoreactive (Fig. 2). As shown by double-labeling experiments with an antiserum against cGMP, the most robust SOD-ir was expressed by neurons showing cGMP-ir (Fig. 2). Pre- viously we showed that, between $\mathrm{P} 7 / 8$ and $\mathrm{P} 12 / 13,50-100$ local interneurons in the lateral cell group are rendered cGMP positive (Schachtner et al., 1998). cGMP elevation in these neurons seems to be due mainly to NO-sensitive soluble guanylyl cyclases (Schachtner et al., 1999; Schachtner, unpublished data) with NO likely released from the olfactory receptor neurons (Gibson and Nighorn, 2000). SOD-ir especially in these local interneurons suggests that SOD may play a role in prolonging NO signaling. Preliminary results obtained from pharmacological experiments during this time of development suggest a role of the NO/cGMP signaling pathway in enhancing synaptogenesis in the developing glomeruli (Schachtner, 2001; Schachtner, unpublished results).

Malun et al. (1994) showed that uniglomerular projection neurons (uPNs) of the medial cell group are the first antennal lobe neurons contacting olfactory receptor neurons before glomeruli formation. These uPNs, as with the olfactory receptor neurons, are able to form tufted dendritic trees and are thought to play a role in building the glomerular template (Malun et al., 1994). During this period of extensive dendritic and axonal growth, no SOD-ir was detected in the medial cell group. We hypothesize that SOD-ir may be a correlate of metabolic activity. The correlation of SOD-ir with synaptogenesis in the lateral cell group may indicate that the metabolism is particularly high during massive synapse formation, i.e., higher than during axonal and dendritic growth. Thus, SOD-ir might be primarily a marker for neuronal maturation, but not for neuronal growth. Then, the cells of the lateral cell group might be more involved in building up the primary glomerular network than the medial cell group between P7/8 and P11/12.

The pattern of SOD-ir in the lateral cell group changed dramatically after adult eclosion, with some somata showing robust SOD-ir, comparable to the signal intensity observed earlier in development, whereas others showing weak staining. Double-labeling experiments with the sGC $\alpha 1$ antiserum revealed colocalization of sGC $\alpha 1$-ir in a subpopulation of the weakly SOD-immunoreactive cells (Fig. 2D). As discussed earlier, SOD in the sGC $\alpha 1$-positive cells might help to increase the longevity of NO. The function of the strongly SOD-positive neurons is unknown, but it is possible that they undergo a last refinement of synaptic connectivity in the glomeruli to cope with odor information provided from the olfactory receptor neurons.

\section{Optic lobe development}

The optic lobe is a highly retinotopically ordered neuropil that consists of three distinguishable neuropils, most distally the lamina, followed by the medulla and the lobula complex, the anterior lobula, and the posterior lobula plate (Bullock and Horridge, 1965; Strausfeld, 1976; Homberg, 1994). In M. sexta, the optic anlagen, from which the optic lobes develop, are readily apparent in the third larval instar (Monsma and Booker 1996a). We never observed SOD-ir in the optic anlagen, which contrasts with findings of Klichko et al. (1999), who found reporter gene expression of the promoter domain of $\mathrm{Cu} / \mathrm{Zn}$ SOD in proliferating neuroblasts of $D$. melanogaster. Because we began to test for SOD labeling only after the beginning of wandering behavior (W0), we may have missed a large part of the neuroblasts' proliferation period, during which they could have transiently expressed SOD. On the other 
hand, the neuroblasts of the optic anlagen produce ganglion mother cells far into pupal development, and programmed cell death of these neuroblasts does not occur before P7 (Monsma and Booker, 1996a; Champlin and Truman, 1998). Also, we never found SOD-ir in neuroblasts undergoing programmed cell death (shown by using the TUNEL technique; Fig. 3D), supporting the hypothesis that such cells do not up-regulate SOD for protection against ROS.

In addition, it has been reported that neuroblasts of the optic anlagen in $M$. sexta contain NO synthase (NOS) from the beginning of the fifth larval instar, which is the time when the neuroblasts shift to produce optic lobe neurons (Champlin and Truman 2000). Because no SOD-ir could be found, we suggest that the neuroblasts in the optic anlagen in $M$. sexta are protected against ROS by mechanisms other than SOD.

From stage P3/4 onward, most somata located distally and adjacent to the three developing optic neuropils showed strong SOD-ir. This pattern of SOD-ir terminated first (at P8) in the cells distal to the lamina, then in the cells distal to the medulla, followed by cells in the lobula complex (at P11). Most, if not all, of the cells distal to the lamina are probably lamina monopolar cells that form the lamina neuropil together with the axons of the photoreceptor cells. The cells distal to medulla and lobula complex, together with the neurons at the basis of the lamina and medulla (bLM neurons) form the other two optic lobe neuropils. Because of their location, the bLM neurons may develop into tangential neurons of the medulla and lobula complex and into the putative lobula giant neurons LoGs (Homberg and Hildebrand, 1994). They are SOD positive from $\mathrm{P} 1 / 2$ to $\mathrm{A} 1 / 2$.

If our hypothesis is correct that SOD expression is an indicator for synaptogenesis, the network assemblage of the three optic lobes would start at P1/2 in the medulla and lobula complex (at P1/2) with the bLM neurons and the LoGs. One to two days later (at P3/4), cells distal to all three optic lobe neuropils are recruited. Because of their position, these cells are very likely to be involved in building the columnar organization of the optic neuropils, which is finished at P11. According to the time course of the SOD-ir of the cells distal to the lamina (lamina monopolar cells), the assemblage of lamina neuropil would start at P3/4 and would then mostly be finished at P8, whereas some areas might be under construction up to P11, insofar as some scattered cells showed SOD-ir up to this time.

The involvement of NO in optic lobe development has been shown for Drosophila and Manduca (Gibbs and Truman, 1998; Champlin and Truman, 2000). In Manduca, NO in concert with the developmental hormone 20hydroxyecdysone, but without the involvement of cGMP, stops neuroblast proliferation (Champlin and Truman 2000). Previously, we described neurons of the group of bLM neurons that transiently enhanced their cGMP levels during optic lobe metamorphosis (Schachtner et al. 1998). These ventral ( $\mathrm{VCl}$ ) and dorsal (DCl) cluster neurons show additional immunolabeling with the antiserum against the $\alpha 1$ subunit of soluble guanylyl cyclase (Schachtner et al., 1998; Schachtner, unpublished results). Transient cGMP increases in both cell clusters occur in the developmental window of robust SOD-ir within the bLM neurons. Double labeling with the SOD and cGMP antisera re- vealed that in the $\mathrm{VCl}$ all neurons showing cGMP-ir colocalized SOD-ir, whereas in the DCl not all neurons positive for cGMP contained SOD-ir. Thus, in most neurons of the two cell clusters, SOD might support NO signaling during development by protecting NO from being degraded by ROS.

\section{Other brain areas}

In the central brain, many neurons showed SOD-ir. We followed four groups of cells during metamorphosis, which occupied similar positions in the brain throughout development. As for the Kenyon cells and the large medial tritocerebral neurons (MT neurons; Schachtner et al., 1998), we are confident that we described SOD-ir pattern in the same neurons throughout metamorphosis. As far the neurons in the pars intercerebralis (PI neurons) and the neurons in the lateral protocerebrum (LP neurons) are concerned, we might have described different neurons with changing SOD-ir in a similar location.

The Kenyon cells are the principal neurons of the mushroom bodies (MBs; Heisenberg, 1998; Menzel, 2001). The cell bodies of the Kenyon cells reside in the calyx area, with their neurites projecting into the calyx and their axons projecting into the pedunculus and the various lobes (Schürmann, 1987; Homberg, 1994). In contrast to the antennal and optic lobes, the MBs exist already in the larva. In Drosophila, the MBs are built from four neuroblasts per hemisphere, which continue to proliferate from the embryo up to late metamorphosis (Ito and Hotta, 1992). In other insects, the proliferation phase continues into adulthood, underscoring the plasticity of this brain structure (Cayre et al., 1996). Elegant experiments in Drosophila showed that Kenyon cell axons degenerate during the first 24 hours of pupal development and that pruning of new imaginal fibers occurs later, while new cell bodies are added steadily (Technau and Heisenberg, 1982).

In $M$. sexta development of the MB has so far not been studied. Transient SOD-ir in their Kenyon cells can be divided into five phases. If SOD expression is an indicator for synapse formation, the changes in SOD-ir during phases 1-5 may reflect the dynamics of the MB network assemblage as described above for Drosophila.

In conclusion, our data indicate changes of SOD-ir during larval, pupal, and adult development in $M$. sexta, suggesting that SOD may be an important defense mechanism against ROS in developing brain structures. This conclusion is supported by the fact that SOD-ir appears transiently during phases of neuronal maturation. SOD may protect cells from oxidative stress, so the presence of SOD-ir during synapse formation might indicate that, during this event, the buildup of ROSs is greater than during other developmental events, i.e., axon growth and dendrite formation. However, we also found neurons in the pars intercerebralis, in the lateral protocerebrum, and in the median tritocerebrum, which showed SOD-ir during long periods. These cells have large diameters and are in areas in which many neurosecretory cells are located. SOD-ir within these cells might thus reflect high metabolic rates in terms of producing and releasing peptides or biogenic amines. Additionally, many NO-sensitive neurons showed SOD-ir, suggesting a role of SOD in securing $\mathrm{NO}$ action. 


\section{ACKNOWLEDGMENTS}

We thank Dr. Jan DeVente for kindly providing the cGMP antiserum and Dr. Kaushiki P. Menon for providing the synaptotagmin antibody. We also thank Drs. Uwe Homberg, Achim Paululat, and Martin Klingenspor for providing the various brain tissues and Lucia Lennarts and Sabine Jesberg for their expert technical assistance.

\section{LITERATURE CITED}

Ames BN, Shigenaga MK, Hagen TM. 1993. Oxidants, antioxidants, and the degenerative diseases of aging. Proc Natl Acad Sci USA 90:79157922 .

Beckman JS, Koppenol WH. 1996. Nitric oxide, superoxide, and peroxynitrite: the good, the bad, and ugly. Am J Physiol 271:1424-1437.

Beckman JS, Estevez AG, Crow JP, Barbeito L. 2001. Superoxide dismutase and the death of motoneurons in ALS. Trends Neurosci 24:1520 .

Bradford MM. 1976. A rapid and sensitive method for the quantitation of microgram quantities of protein utilizing the principle of protein-dye binding. Anal Biochem 72:248-254.

Bullock TH, Horridge GA. 1965. Structure and function in the nervous system of invertebrates, vol II. San Francisco: W.H. Freeman.

Cayre M, Strambi C, Charpin P, Augier R, Meyer MR, Edwards JS, Strambi A. 1996. Neurogenesis in adult insect mushroom bodies. J Comp Neurol 371:300-310.

Champlin DT, Truman JW. 1998. Ecdysteroid control of cell proliferation during optic lobe neurogenesis in the moth Manduca sexta. Development 125:269-277.

Champlin DT, Truman JW. 2000. Ecdysteroid coordinates optic lobe neurogenesis via a nitric oxide signaling pathway. Development 127:35433551.

DeVente J, Steinbusch HWM, Schipper J. 1987. A new approach to immunocytochemistry of $3^{\prime} 5^{\prime}$-cyclic guanosine monophosphate: preparation, specificity, and initial application of a new antiserum against formaldehyde fixed 3'5'-cyclic guanosine monophosphate. Neuroscience 22:361-373.

Draizen TA, Ewer J, Robinow S. 1999. Genetic and hormonal regulation of the death of peptidergic neurons in the Drosophila central nervous system. J Neurobiol 38:455-465.

Dubuque SH, Schachtner J, Nighorn AJ, Menon KP, Zinn K, Tolbert LP. 2001. Immunolocalization of synaptotagmin for the study of synapses in the developing antennal lobe of Manduca sexta. J Comp Neurol 441:277-287.

Ewer J, De VJ, Truman JW. 1994. Neuropeptide induction of cyclic GMP increases in the insect CNS: resolution at the level of single identifiable neurons. J Neurosci 14:7704-7712.

Ewer J, Wang CM, Klukas KA, Mesce KA, Truman JW, Fahrbach SE. 1998. Programmed cell death of identified peptidergic neurons involved in ecdysis behavior in the moth, Manduca sexta. J Neurobiol 37:265280.

Floyd RA. 1999. Antioxidants, oxidative stress, and degenerative neurological disorders. Proc Soc Exp Biol Med 222:236-245.

Frayn KN. 1996. Metabolic regulation. In: Snell K, editor. Frontiers in metabolism, 1 series. Portland: Portland Press.

Fridovich I. 1986. Superoxide dismutases. Adv Enzymol Relat Areas Mol Biol 58:61-97.

Fridovich I. 1999. Fundamental aspects of reactive oxygen species, or what's the matter with oxygen? Ann N Y Acad Sci 893:13-18.

Friebe A, Schultz G, Koesling D. 1998. Stimulation of soluble guanylate cyclase by superoxide dismutase is mediated by NO. Biochem J 335: 527-531.

Gavrielli Y, Sherman Y, Ben-Sasson SA. 1992. Identification of programmed cell death in situ via specific labeling of nuclear DNA fragmentation. J Cell Biol 119:493-501.

Gibbs SM, Truman JW. 1998. Nitric oxide and cyclic GMP regulate retinal patterning in the optic lobe of Drosophila. Neuron 20:83-93.

Gibson NJ, Nighorn A. 2000. Expression of nitric oxide synthase and soluble guanylyl cyclase in the developing olfactory system of Manduca sexta. J Comp Neurol 422:191-205.

Griswold CM, Matthews AL, Bewley KE, Mahaffey JW. 1993. Molecular characterization and rescue of acatalasemic mutants of Drosophila melanogaster. Genetics 134:781-788.
Heisenberg M. 1998. What do the mushroom bodies do for the insect brain? An introduction. Learn Mem 5:1-10.

Hildebrand JG, Rössler W, Tolbert LP. 1997. Postembryonic development of the olfactory system in the moth Manduca sexta: primary-afferent control of glomerular development. Cell Dev Biol 8:163-170.

Homberg U. 1994. Distribution of neurotransmitters in the insect brain. Stuttgart: Gustav Fischer Verlag.

Homberg U, Hildebrand JG. 1989. Serotonin immunoreactivity in the optic lobes of the sphinx moth Manduca sexta and colocalisation with FMRFamide and SCPB immunoreactivity. J Comp Neurol 288:243-253.

Homberg U, Hildebrand JG. 1994. Postembryonic development of gammaaminobutyric acid-like immunoreactivity in the brain of the sphinx moth Manduca sexta. J Comp Neurol 339:132-149.

Homberg U, Kingan TG, Hildebrand JG. 1987. Immunocytochemistry of GABA in the brain and suboesophageal ganglion of Manduca sexta. Cell Tissue Res 248:1-24.

Homberg U, Montague RA, Hildebrand JG. 1988. Anatomy of antennocerebral pathways in the brain of the sphinx moth Manduca sexta. Cell Tissue Res 254:255-281.

Homberg U, Kingan TG, Hildebrand JG. 1990. Distribution of FMRF amide-like immunoreactivity in the brain and suboesophageal ganglion of the sphinx moth Manduca sexta and colocalization with SCPB-, BPP-, and GABA-like immunoreactivity. Cell Tissue Res 259:401-419.

Ito K, Hotta Y. 1992. Proliferation pattern of postembryonic neuroblasts in the brain of Drosophila melanogaster. Dev Biol 149:134-148.

Jindra M, Huang JY, Malone F, Asahina M, Riddiford LM. 1997. Identification of mRNA developmental profiles of two ultraspiracle isoforms in the epidermis and wings of Manduca sexta. Insect Mol Biol 6:41-53.

Klichko VI, Radyuk SN, Orr WC. 1999. CuZn-SOD promoter-driven expression in the Drosophila central nervous system. Neurobiol Aging 20:537-543.

Kostron B, Market D, Kellermann J, Carter CE, Honegger HW. 1999. Antisera against Periplaneta americana $\mathrm{Cu}, \mathrm{Zn}$-superoxide dismutase (SOD): separation of the neurohormone bursicon from SOD, and immunodetection of SOD in the central nervous system. Insect Biochem Mol Biol 29:861-871.

Ku DK. 1996. Nitric oxide and nitric oxide donor-induced relaxation. In: Packer L, editor. Methods in enzymology, vol 269, part B. New York: Academic Press. p 107-119.

Kwiatowski J, Skarecky D, Tyler R, Pascual M, Ayala FJ. 1991. A truncated $\mathrm{P}$ element is inserted in the transcribed region of the $\mathrm{Cu}, \mathrm{Zn}$ SOD gene of an SOD "null" strain of Drosophila melanogaster. Free Radic Res Commun 12/13:429-435.

Lindenau J, Noack H, Possel H, Asayama K, Wolf G. 2000. Cellular distribution of superoxide dismutases in the rat CNS. Glia 29:25-34.

Linton S, Davies MJ, Dean RT. 2001. Protein oxidation and ageing. Exp Gerontol 36:1503-1518.

Mackay WJ, Bewley GC. 1989. The genetics of catalase in Drosophila melanogaster: isolation and characterization of acatalasemic mutants. Genetics 122:643-652.

Maier CM, Chan PH. 2002. Role of superoxide dismutases in oxidative damage and neurodegenerative disorders. Neuroscientist 8:323-334.

Malun D, Oland LA, Tolbert LP. 1994. Uniglomerular projection neurons participate in early development of olfactory glomeruli in the moth Manduca sexta. J Comp Neurol 350:1-22.

Markesbery WR. 1997. Oxidative stress hypothesis in Alzheimer's disease. Free Radic Biol Med 23:134-147.

Menzel R. 2001. Searching for the memory trace in a mini-brain, the honeybee. Learn Mem 8:53-62.

Mockett RJ, Orr WC, Sohal RS. 2002. Overexpression of Cu,ZnSOD and MnSOD in transgenic Drosophila. Methods Enzymol 349:213-220.

Monsma SA, Booker R. 1996a. Genesis of the adult retina and outer optic lobes of the moth, Manduca sexta. I. Patterns of proliferation and cell death. J Comp Neurol 367:10-20.

Monsma SA, Booker R. 1996b. Genesis of the adult retina and outer optic lobes of the moth Manduca sexta. II. Effects of deafferentiation and developmental hormone manipulation. J Comp Neurol 367:21-35.

Nagy IZ. 2001. On the true role of oxygen free radicals in the living state, aging, and degenerative disorders. Ann N Y Acad Sci 928:187-199.

Okado-Matsumoto A, Fridovich I. 2002. Amyotrophic lateral sclerosis: a proposed mechanism. Proc Natl Acad Sci USA 99:9010-9014.

Oland LA, Tolbert LP. 1996. Multiple factors shape development of olfactory glomeruli: insights from an insect model system. J Neurobiol 30:92-109. 
Oland LA, Tolbert LP. 1998. Glomerulus development in the absence of a set of mitral-like neurons in the insect olfactory lobe. J Neurobiol 36:41-52.

Orr WC, Arnold LA, Sohal RS. 1992. Relationship between catalase activ ity, life span and some parameters associated with antioxidant defenses in Drosophila melanogaster. Mech Ageing Dev 63:287-296.

Oury TD, Card JP, Klann E. 1999. Localization of extracellular superoxide dismutase in adult mouse brain. Brain Res 850:96-103.

Phillips JP, Campbell SD, Michaud D, Charbonneau M, Hilliker AJ. 1989 Null mutation of copper/zinc superoxide dismutase in Drosophila confers hypersensitivity to paraquat and reduced longevity. Proc Nat Acad Sci USA 86:2761-2765.

Schachtner J. 2001. Involvement of NO and cGMP in antennal lobe development of the sphinx moth Manduca sexta. Soc Neurosci Abstr 27 140.6 .

Schachtner J, Klaassen L, Truman JW. 1998. Metamorphic control of cycli guanosine monophosphate expression in the nervous system of the tobacco hornworm, Manduca sexta. J Comp Neurol 396:238-252.

Schachtner J, Homberg U, Truman JW. 1999. Regulation of cyclic GMP elevation in the developing antennal lobe of the sphinx moth, Manduca sexta. J Neurobiol 41:359-375.

Schürmann F-W. 1987. The architecture of the mushroom bodies and related neuropiles in the insect brain. In: Gupta AP, editor. Arthropod brain: its evolution, development, structure and functions. New York: John Wiley \& Sons. p 231-264.

Schwartz LM, Truman JW. 1983. Hormonal control of rates of metamorphic development in the tobacco hornworm Manduca sexta. Dev Biol 99:103-114

Sohal RS. 1993. The free radical hypothesis of aging: an appraisal of the current status. Aging 5:3-17.

Stadtman ER. 2001. Protein oxidation in aging and age-related diseases. Ann N Y Acad Sci 928:22-38.
Strausfeld NJ. 1976. Atlas of an insect brain. Berlin: Springer.

Sun J, Tower J. 1999. FLP recombinase-mediated induction of $\mathrm{Cu} / \mathrm{Zn}$ superoxide dismutase transgene expression can extend the life span of adult Drosophila melanogaster flies. Mol Cell Biol 19:216-228.

Sun J, Folk D, Bradley TJ, Tower J. 2002. Induced overexpression of mitochondrial Mn-superoxide dismutase extends the life span of adult Drosophila melanogaster. Genetics 161:661-672.

Tabner BJ, Turnbull S, El Agnaf O, Allsop D. 2001. Production of reactive oxygen species from aggregating proteins implicated in Alzheimer's disease, Parkinson's disease and other neurodegenerative diseases. Curr Top Med Chem 1:507-517.

Technau G, Heisenberg M. 1982. Neural reorganization during metamorphosis of the corpora pedunculata in Drosophila melanogaster. Nature 295:405-407.

Tolbert LP. 1989. Afferent axons from the antenna influence number and placement of intrinsic synapses in the antennal lobe of Manduca sexta. Synapse 3:83-95.

Tolbert LP, Matsumoto SG, Hildebrand JG. 1983. Development of synapses in the antennal lobes of the moth Manduca sexta during metamorphosis. J Neurosci 3:1158-1175.

Truman JW. 1996. Metamorphosis of the insect nervous system. In: Gilbert LI, editor. Metamorphosis: postembryonic reprogramming of gene expression in amphibian and insect cells. Orlando, FL: Academic Press. p $283-320$.

Watson AHD, Burrows M. 1981. Input and output synapses on identified motor neurones of a locust revealed by intracellular injection of horseradish peroxidase. Cell Tissue Res 215:325-332.

Weeks JC. 1999. Steroid hormones, dendritic remodeling and neuronal death: insights from insect metamorphosis. Brain Behav Evol 54:5160 .

Weevers RD. 1966. A lepidopteran saline: the effects of inorganic cation concentrations on sensory reflex and motor responses in a herbivorous insect. J Exp Biol 44:163-176. 